\title{
Peningkatan Pengetahuan dan Keterampilan Pangkas Rambut Di Kenagarian Sariak Laweh Kecamatan Akabiluru Kabupaten 50 Kota
}

\author{
Hayatunnufus $\left.{ }^{*}\right) 1$, Merita Yanita ${ }^{2}$, Siska Miga Dewi ${ }^{3}$ \\ 123Pendidikan Tata Rias dan Kecantikan/FPP/Universitas Negeri Padang \\ *)Corresponding author, Ð hayatunnufus@fpp.unp.ac.id
}

(Revisi) 10/06/2019; Diterima 25/06/2019; Publish 08/08/2019
Kata kunci:

Pengabdian kepada Masyarakat,PKK, Pangkas Rambut

\begin{abstract}
Abstrak
Kegiatan pengabdian ini dilatarbelakangi oleh permintaan dari ibu-ibu PKK Kenagarian Sariak Laweh, Kecamatan Akabiluru, Kabupaten 50 Kota untuk memberikan pelatihan tentang pangkas rambut dalam rangka meningkatkan keterampilan ibu-ibu anggota PKK. Adapun tujuannya (1) memiliki wawasan kemampuan dan keterampilan tentang pemangkasan rambut, (2) meningkatkan mutu proses dan hasil pemangkasan rambut, (3) menumbuhkembangkan keterampilan bidang pangkas rambut sehingga bermanfaat untuk diri sendiri dan orang lain, (4) memberi peluang untuk membuka usaha dan meningkatkan usahanya di bidang pangkas rambut sehingga menambahkan in come bagi keluarga. Target luaran kegiatan ini jurnal berISSN dan video kegiatan. Target yang akan dicapai yaitu meningkatkan keterampilan pangkas rambut dan meningkatkan penghasilan keluarga. Kegiatan ini dilaksanakan di PKK Kenagarian Sariak Laweh, Kecamatan Akabiluru, Kabupaten 50 Kota yang pesertanya terdiri dari 15 orang. Kegiatan ini dilakukan dengan metode ceramah untuk menyampaikan konsep dasar pemangkasan rambut, demonstrasi bagaimana cara melakukan pangkas rambut, tanya jawab, pelatihan pemangkasan rambut dan diberi bimbingan serta metode resitasi pada saat pelatihan.Hasil yang dicapai pada kegiatan ini peserta memperoleh informasi, penyuluhan, serta keterampilan pangkas rambut, sehingga diharapkan peserta pelatihan membuka usaha salon kecantikan khususnya di bidang pangkas rambut. Hasil penelitian terhadap penilaian program, sangat setuju $56,7 \%$, setuju $43,3 \%$, dan kepuasan $73,3 \%$ sangat setuju, $26,7 \%$ setuju.
\end{abstract}




\section{PENDAHULUAN}

\section{ANALISIS SITUASI}

Perkembangan zaman saat sekarang sangat maju pesat terutama di bidang ilmu pengetahuan dan tekonologi. Seiringan dengan kemajuan tersebut, kebutuhan masyarakat bertambah banyak pula. Ini ditandai dengan semakin meningkatnya pengeluaran keluarga setiap bulannya, sementara masyarakat kita masih banyak yang belum dapat memenuhi kebutuhan tersebut karena terbatasnya penghasilan kepala keluarga (suami). Untuk mengatasi masalah tersebut, peran ibu dalam keluarga mulai bergeser sebagai pencari uang tambahan. Untuk itu dituntut memiliki pendidikan, keterampilan untuk dapat berperan ganda sebagai pekerja di luar rumah untuk menambah penghasilan keluarga disamping kerja pokoknya sebagai ibu rumah tangga.

Jorong Koto Malintang merupakan salah satu jorong dari kenagarian Sariak Laweh dengan jumlah penduduk sekitar $150 \mathrm{KK}$. Berdasarkan observasi yang dilakukan di jorong Koto Malintang Kenagarian Sariak Laweh, Kecamatan Akabiluru, Kabupaten 50 Kota, banyak diantara ibu-ibu rumah tangga yang berminat meningkatkan keterampilannya, dari data yang diperoleh sebanyak 15 orang berminat untuk meningkatkan keterampilannya di bidang rambut terutama pangkas rambut. Rostamailis, dkk. (2008:80) secara Ethymologi pangkas adalah tindakan memotong yang sudah dilakukan sejak zaman dahulu, dengan cara yang sederhana dengan perkembangan zaman dan tuntutan masyarakat pada saat itu. pemangkasan rambut adalah suatu tindakan untuk mengurangi panjang rambut semula dengan teknik tertentu sesuai dengan bentuk wajah, jenis rambut, perawakan dan kepribadian seseorang yang menghasilkan model pemangkasan yang diinginkan dan termasuk kedalam proses penataan rambut. Tujuan dari pemangkasan ini adalah mengurangi panjang rambut, merapikan rambut, merubah penampilan serta mengikuti mode yang telah berkembang. Oleh karena itu, kami dari Tim Pengabdian UNP memilih PKK Kenagarian Sariak Laweh, Kecamatan Akabiluru, Kabupaten 50 Kota sebagai lembaga mitra yang dapat membantu kelancaran pelaksanaan kegiatan pelatihan keterampilan pangkas rambut yang selalu dibutuhkan masyarakat Sumatera Barat pada umumnya terutama dalam penyediaan prasarana dan fasilitas lainnya yang dibutuhkan dalam pelatihan pangkas rambut tersebut.

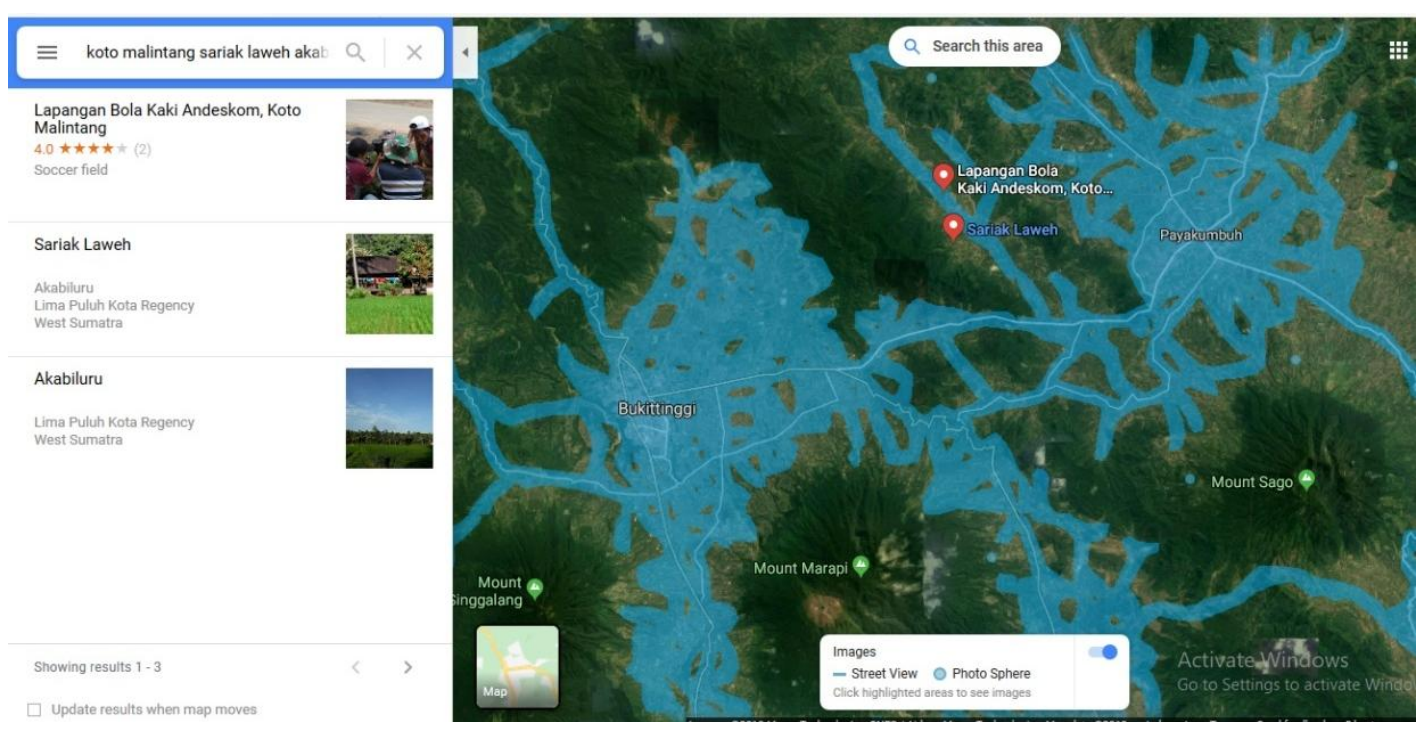

Gambar 1. Peta Nagari Sariak Laweh 


\section{Suluah Bendang: Jurnal IImiah Pengabdian Kepada Masyarakat}

Vol.19, No.1, 2019

Hayatunnufus, Merita Yanita, Siska Miga Dewi

\section{SOLUSI DAN TARGET}

Dalam memecahkan masalah yang ada pada ibu-ibu PKK di jorong Koto Malintang Kenagarian Sariak Laweh, Kecamatan Akabiluru, Kabupaten 50 Kota, maka mitra dan pelaksana PKM sepakat untuk memecahkan masalah dalam hal:

Pelatihan keterampilan pemangkasan rambut bagi ibu-ibu PKK dalam rangka membekali mereka dengan keterampilan yang dibutuhkannya untuk menambah penghasilan keluarga.

1. Melaksanakan pelatihan bagi ibu-ibu PKK oleh instruktur yang profesional di bidang tata rias dan kecantikan.

2. Memberikan pelatihan tentang strategi membangkitkan minat berusaha bagi ibu-ibu PKK serta mengembangkan keterampilan yang sesuai dengan kebutuhannya.

3. Peningkatan pemahaman dan aplikasi nilai-nilai karakter bangsa yang dapat dijadikan sebagai pendukung dalam meningkatkan keterampilan pemangkasan rambut bagi ibu-ibu PKK.

Prosedur yang diberikan dalam pelaksanaan pengabdian kepada masyarakat ini adalah sebagai berikut:

1. Teori:

a. Konsep dasar pemangkasan

b. Peralatan untuk pemangkasan

c. Metode, pola dan teknik pemangkasan

d. Bentuk-bentuk pemangkasan desain

2. Praktek

a. Pemangkasan pola mendatar

b. Pemangkasan bertingkat (graduation cut)

c. Pemangkasan garis $\mathrm{V}$

d. Pemangkasan berlapis (layered cut)

Pada kegiatan ini pemberian pengetahuan yang bersifat teori, disampaikan melalui metode ceramah dan tanya jawab. Sedangkan materi praktek yang diberikan terlebih dahulu di demonstrasikan, kemudian diikuti oleh peserta dan dibimbing langsung oleh instruktur.

Adapun target yang akan dicapai pada pengabdian ini adalah:

1. Bertambahnya pengetahuan ibu-ibu PKK tentang pangkas rambut.

2. Bertambahnya keterampilan ibu-ibu PKK di bidang pangkas rambut.

3. Terjadi peningkatan dan pengembangan ekonomi pada ibu-ibu PKK di jorong Malintang Kenagarian Sariak Laweh Kecamatan Akabiluru Kabupaten 50 Kota

\section{METODE PELAKSANAAN}

\section{Tempat dan Waktu}

Pengabdian kepada masyarakat ini dilakukan pada tanggal 29 Juli sampai 3 Agustus 2019 di jorong Koto Malintang kenagarian Sariak Laweh kecamatan Akabiluru kabupaten 50 Kota.

\section{Khalayak Sasaran}

Khalayak sasaran dalam kegiatan pengabdian ini adalah ibu-ibu PKK jorong Koto Malintang kenagarian Sariak Laweh kecamatan Akabiluru kabupaten 50 Kota sebanyak 15 orang. Peserta merupakan ibu-ibu anggota PKK yang bersedia menerima pelatihan pangkas rambut sesuai dengan perencanaan kegiatan yang akan dilakukan oleh Tim Pengabdian UNP.

\section{Metode Pengabdian}

Pelaksanaan pelatihan digunakan metode yang bervariasi yaitu: 
1. Metode ceramah dan tanya jawab untuk memperkenalkan jenis keterampilan yang akan diberikan.

2. Metode demonstrasi untuk proses pemangkasan rambut.

3. Metode palatihan dan bimbingan digunakan dalam penerapan praktek oleh para peserta selama kegiatan, mulai dari persiapan alat dan bahan kosmetika, proses kerja pangkas rambut, hingga hasil pangkas rambut, serta umpan balik untuk mengetahui tingkat kemajuan peserta.

4. Metode resitasi atau pemberian tugas yang dilakukan di rumah guna melatih keterampilan peserta.

\section{Indikator Keberhasilan}

Indikator keberhasilan dalam kegiatan pengabdian kepada masyarakat ini adalah bertambahnya pengetahuan dan keterampilan ibu-ibu PKK di bidang pangkas rambut. Selain itu terjadi peningkatan dan pengembangan ekonomi pada ibu-ibu PKK di jorong Malintang Kenagarian Sariak Laweh Kecamatan Akabiluru Kabupaten 50 Kota.

\section{Metode Evaluasi}

Evaluasi dilakukan tiga tahap yang meliputi evaluasi persiapan, evaluasi proses dan evaluasi hasil. Rancangan evaluasi tersebut adalah sebagai berikut:

1. Evaluasi awal: dilakukan dengan cara mengadakan tanya jawab tentang jenis keterampilan yang akan dilatihkan untuk mengetahui sejauh mana tingkat pengetahuan peserta tentang keterampilan dalam pangkas rambut.

2. Selama proses: dilakukan dengan cara melihat keterlibatan, keantusiasan dalam mengikuti kegiatan.

3. Pada akhir proses dilakukan kegiatan evaluasi hasil praktek peserta yaitu evaluasi pangkas rambut.

\section{HASIL DAN PEMBAHASAN}

Hasil yang dicapai pada kegiatan pelatihan ini terdiri dari dua aspek, yaitu: (1) kegiatan pelatihan yang berkaitan dengan keterampilan pangkas rambut baik pemangkasan dasar maupun pemangkasan barber yang diperoleh peserta selama melaksanakan kegiatan pelatihan, (2) deskripsi hasil yang diperoleh berkaitan tentang penilaian peserta pelatihan terhadap program pengabdian dan kepuasan peserta terhadap pelatihan yang dilaksanakan. Untuk lebih jelasnya hasil yang dicapai pada kegiatan pengabdian kepada masyarakat ini akan diuraikan sebagai berikut:

\section{Pelatihan Pangkas Rambut}

Berdasarkan pengamatan yang dilakukan selama melaksanakan pelatihan keterampilan pangkas rambut, peserta sangat serius dan antusias dalam mengikuti kegiatan pelatihan, hal ini dibuktikan dari kehadiran peserta yang datang tepat waktu. Hasil yang diperoleh setelah pelatihan dilakukan peserta sudah dapat melakukan: (1) pada kegiatan awal melakukan pangkas rambut dasar dengan pola solid, hampir 90\% peserta sudah dapat melakukan pemangkasan dasar, (2) kegiatan selanjutanya pemangkasan barber yang diperuntukan untuk pangkas rambut pria, kegiatan ini dilakukan peserta dengan baik sekitar $80 \%$ peserta mampu melakuakn pemangkasan barber. Untuk kelanjutan program ini diharapkan pada peserta untuk mengembangkan keterampilan pangkas rambut sehingga dapat dijadikan sebagai sumber mata pencaharian tambahan bagi ibu-ibu PKK sehingga menambah income keluarga.

\section{Penilaian Program dan Kepuasan Peserta}

Berdasarkan proses pelatihan keterampilan pangkas rambut, kami dari Tim pengabdian melakukan penilaian yang berkaitan dengan program dan kepuasan peserta pelatihan terhadap 


\section{Suluah Bendang: Jurnal Ilmiah Pengabdian Kepada Masyarakat}

Vol.19, No.1, 2019

Hayatunnufus, Merita Yanita, Siska Miga Dewi

kegiatan pengabdian yang dilaksanakan. Ditinjau dari penilaian program, 57\% peserta sangat setuju bahwa program pengabdian ini dapat memberikan pengetahuan dan keterampilan di bidang pangkas rambut sehingga menambah in come bagi keluarga, dan 43\% lainnya menyatakan setuju. Ditinjau dari kepuasan peserta pelatihan, $73 \%$ peserta menyatakan sangat setuju dengan kepuasan merka dalam pelaksanaan program pengabdian ini dan $27 \%$ menyatakan setuju. Jadi jika kegiatan ini dilakukan kembali mereka sangat antusias untuk berpartisipasi kembali sebagai peserta pelatihan dalam program pengabdian kepada masyarakat.

\section{KESIMPULAN}

Berdasarkan pelatihan keterampilan pangkas rambut bagi ibu-ibu PKK di jorong Koto Malintang kelurahan Sariak Laweh kecamatan Akabiluru kabupaten 50 Kota, maka dapat disimpulkan; (a) Para peserta pelatihan mempunyai keinginan yang tinggi untuk mengikuti pelatihan yang dibuktikan dari kehadiran peserta, (b) Tujuan peserta mengikuti pelatihan agar peserta terampil melakukan pangkas rambut sehingga dapat membuka usaha salon kecantikan khususnya pangkas rambut, (c) Para peserta pelatihan mulai terampil dalam melakukan pangkas rambut, dan (d) Sebahagian peserta berminat untuk membuka usaha salon untuk menambah penghasilan keluarga. Adapun luaran yang dihasilkan dari pengabdian ini adalah jurnal pengabdian kepada masyarakat yang ber-ISSN dan video kegiatan yang di upload di youtube.

Sehubungan dengan hasil yang telah di peroleh melalui kegiatan ini, berikut di kemukakan beberapa saran, yaitu: (a) Diharapkan para peserta untuk latihan secara continue, sehingga dapat lebih trampil lagi dalam melakukan pangkas rambut, (b) Diharapkan para peserta memberanikan diri untuk terjun langsung dalam melakukan pangkas rambut dengan berbagai model pangkas rambut, sehingga bisa memperoleh masukan dari masyarakat pengguna jasa, dan (c) Diharapkan para peserta untuk menularkan pada anggota lainnya secara bertahap, sehigga dapat menambah penghasilan keluarga.

\section{DAFTAR PUSTAKA}

Marzuki, Saleh. 2012. Pendidikan Non Formal Dimensi dalam Keaksaraan Fungsional, Pelatihan, dan Andragogi. Bandung: Remaja Rosdakarya

Mustika Sari, A. (2017). Penguasaan Keterampilan Pemangkasan Rambut Graduasi Melalui Pelatihan Bagi Santriwati Di Panti Asuhan Al Hidayah Driyorejo Gresik. Jurnal Tata Rias, 6(01).

Rostamailis, dkk. 2008. Tata Kecantikan Rambut Jilid I,DirektoratPembinaan Sekolah Menangah Kejuruan Direktorat Jendral Managemen Pendidikan Dasar dan Menengah Departemen Pendidikan Nasional, Jakarta.

Sihombing, Umberto. 2002. Menuju Pendidikan Bermakna Melalui Pendidikan Berbasis Masyarakat. Jakarta: CV Multiguna

Undang-Undang No. 20 tahun 2003 tentang Sistem Pendidikan Nasional. Bandung: Fokus Media 